volume in hand, and give us a full account of its contents. If the society wishes to render a real and great service to the students of Indian palæography, it will publish photoetchings of the whole volume. Every line of the MS. is of the highest importance.

\title{
G. BühLER.
}

\section{The New Sanskrit MS. prom Mingai.}

Dedham, Essex, Aug. 17, 1891.

Sır,-The "Rain-charm," translated by Prof. Bühler (Academy, August 15, 1891, pp. 138, 139), is certainly Buddhistic, but appears to conform, for the most part, to the North Buddhist type. The Mantra l. 1 contains a list of words which the translator thinks are the names of various plants to be used as ingredients for an oblation; but the Buddhists did not offer sacrifices and oblations. ${ }^{1}$ These terms, therefore, may be merely magical or talismanic words, such as we often find in North Buddhist sutras (see Lotus, ch. xxvi. Kern's Translation S.B.E., pp. 434-5), and are probably epithets of "Civa's female counterpart Durgâ." In the usual invocations we find these magical terms in the vocative case; and perhaps Dundubht, etc. are Prâkrit vocatives for Dundubhr̆, etc. See Megha-sûtra in J.R.A.S. Vol. XII. Pt. 2, p. 301 (1880).

Dundubhî, Garjanî (thundering), Varshanî̀ (raining), Hârinî (? Harinî̀), are the feminines of epithets that could well be applied to Çiva as the representative of Rudra; and Durgâ in the Mantra may be regarded as the devî causing thunder, lightning, and rain. Compare the use of jvalâ, $u k k \hat{a}$, etc., as applied to the goddess Durgâ in the Lotus, ch. xxi. (Kern's Translation, p. 372).

What "cucumber" is I cannot tell, as I have not the Sanskrit text before me; probably $j a ̂ l l$, which is a Prâkrit form of an original *jiâli, " flame," or jyotsnt. fire.

1 In the Tantra ceremonies flesh and even ordure were thrown into the saered 
$S u \hat{a} h \hat{a}=$ "Durgâ," is the usual ending of a $\mathrm{N}$. Buddhist dhâranî. $\quad$ ilikisi $=$ "ilikêsi," is perhaps the vocative of a Prâkrit $i l i k \hat{a}+i c ̧ \hat{\imath}=$ " the earth-goddess."

The Anumantrana contains a list of the Ahirájakulas and Naga-rajas, ${ }^{1}$ which are those usually met with in NorthBuddhist works. We may compare this list with that in the Vardha-varsha-sûtra, entitled in Chinese "The Great Cloud-wheel Rain-asking-sutra" (Beal's Catena, p. 420), the Lotus, etc. :

\begin{tabular}{|c|c|c|c|}
\hline Mingai MS. & Chinese Sutra. & Lotus. & Southern Buddhist. \\
\hline Dhritarâshtra & Dhritarâshtra & Dhritarâshtra & Dhatarattha \\
\hline Nairâvana & & & Erâvana (?) \\
\hline Virûpâksha & Virûpâksha & Virûpâksha & Virûpakkha \\
\hline Krishna & - & - & Kanhâ- \\
\hline Gautamaka & - & - & Gautamaka \\
\hline Mani & & - & Mani-akkhi (?) \\
\hline Vasuki & Vâsuki & Vâsuki & - \\
\hline Dandapâda & 一 & - & - \\
\hline Pûrnabhadra & - & - & - \\
\hline Nanda & Nanda & Nanda & Nanda \\
\hline Upananda & Upananda & Upananda & Upananda \\
\hline Anavatapta & Anavatapta & Anavatapta & Anotatta* \\
\hline Varuna & Varuna & \pm & - \\
\hline Samhâraka & Sâgara & Sâgara & - \\
\hline Takshaka & Takshaka & Takshaka & Tacchaka \\
\hline Ananta & - & 一 & - \\
\hline Vàsumukha & - & 一 & - \\
\hline Aparâjita & - & - & - \\
\hline Chibbấ-putra & - & - & Chabbyâputta \\
\hline Manasvin & Manasvin & - & - \\
\hline - & Mucalinda & 一 & Mucalinda* \\
\hline - & Elapatra (Elapana) & - & Erâpatha \\
\hline - & Pindara & 一 & - \\
\hline 一 & Tejasvin & 一 & - \\
\hline
\end{tabular}

1. Dhritarâstha = the regent of the East; also a Nâgarâja.

2. Naivâvan $a=$ Vaiçravana (Pâli Vessavana = Kuvera), regent of the North (?). It may be a misreading for Airâvana.

3. Virûpâksha = the regent of the West, and also a Nâgarâja. Virûdhaka = the regent of the South, is left out, because he was not regarded as a snake-king. Erâpatha is also omitted, though mentioned in the Chinese Sûtra and the Pâli Jậtaka, etc.

1 In N. Buddhist Sanskrit writers we find about 80 nâgarâjas; the Chinese sutras have over 200 . 
4. Nanda and Upananda are mentioned in Hardy's M. B., second edition, p. 313 . These Nâgarâjas assisted the Devas in a struggle with the Asuras (see Jât. I., p. 204 ; Beal's Catena, pp. 52-55).

5. Anavatapta is not mentioned as a Nâgarâja in Southern Buddhist works; but he was doubtless the guardian of the Anotatta daha (lake), just as Mucalinda was the Nâga king that guarded the Mandâkinî waters. For Mucalinda, the seven-headed snake, see Udâna, p. 10.

6. Samhâraka is evidently a misreading for Sâmgara $=$ Ságara.

7. Chibba = Pâli Chabyâ or Chabbyâ, seems to point to an original *chavikâ (see Cullavagga, v. 6).

8. Pûrna-bhadra and Aparâjita occur in the Mahâbhârata; Vâsumukha = Sumukha (?). Of Dandapâda the legends are silent.

9. Krishna and Gautamaka are mentioned in the Divyâvadâna as two snake-kingss.

R. Morris.

\section{Ceylon Coins.}

Sir,-Robert Knox tells us that, besides Larins and "Pounams" (fanams), there were in circulation other pieces of (silver) money coined by the Portuguese; the King's arms on one side and the image of a friar on the other, and by the Chingulays called tangom massa. The value of one is ninepence English; poddi tangom, or the small tangom, is half as much. The "Chingulay" massa is here, doubtless, the well-known Indian weight, the mãsha (or seed of the Phaseolus vulgaris; see Thomas' "Ancient Indian Weights" in Numismata Orientalia, 1874), which was the quarter of the Sanskrit taika. One meaning of tanka was a "stamped coin," whilst in another sense it was equal to the sataraktika, or weight of 100 ratis (175 grains), forming the early standard of the rupee. A derivative indeed of the Sanskrit taika is the Bengal toakta (whence 